behaviour are independent of current hormonal controls.

The prime emphasis on sex is nicely complemented by chapters on nonreproductive behaviours, including a masterly account by R. M. Sapolsky of the psychosomatic relationship, both normal and pathological, between behaviour and the stress response. Other chapters review the role of hormones in the control of aggression (E. P. Monaghan and S. E. Glickman), feeding and drinking (E. M. Stricker and J. G. Verbalis) responses to the physical environment (R. Silver) and behavioural rhythms in oestrous behaviour, and circadian and circannual cycles (L. P. Morin and J. Dark). The appropriateness may be questioned of some of the more speculative material for an undergraduate text. A wide range of human sex differences in motor functions and cognitive abilities known to vary with phases of the menstrual cycle are assumed to have a direct hormonal basis (Hampson and Kimura), a position that some will dispute. A chapter on "Hormonal Influences on Extrapyramidal Sensorimotor Function and Hippocampal Plasticity" (J. B. Becker) documents hormonal effects on the structure and development of regions of the mammalian brain, but the specific mechanisms linking those changes to behaviour are not always clear. The text seems to be enviably free of errors, apart from a label inversion on a table of dissociation of gonadal activity from mating behaviour (p.157) that contradicts the text.

With such a broad mandate, it is more important for the book to be selective than to be comprehensive, but it is tempting to make suggestions for the next edition. New developments in biology at both ends of the reductionistic-holistic spectrum are ready to be incorporated. A new edition should cover more of the pharmacological and molecular approaches to behavioural endocrinology exemplified by the work of T. R. Insel, K. M. Kendrick, E. B. Keverne, B. S. McEwen and D. W. Pfaff, and the environmental and field endocrinology of physiologically minded behaviourists such as B. K. Follett and J. C. Wingfield, that begins to provide us with top-down explanations of how species differences in mating systems and breeding seasons evolve. More could be done to relate the material on aggression and circadian and circannual rhythms to species differences in natural history and life cycles. The truth is that, despite the exhortations of Beach, we have hardly begun to tap the rich source of new insights into the way in which hormones exert their pervasive effects on brain structure and behaviour that the comparative approach can provide.

Peter Marler is in the Animal Communication Laboratory, University of California, Davis, California 95616-8761, USA.
Inheriting responsibility

Laurence D. Hurst

The Engineer in the Garden. By Colin Tudge. Jonathan Cape: 1993. Pp. 398. £17.99.

Gene Future. By Thomas F. Lee. Plenum Press: 1993. Pp. 339. \$24.95, £19.96.

PERHAPS more than any other discipline, genetic engineering figures in the public eye in an equivocal light. On the one hand, white-coated geneticists are caricatured as the devoted fighters of cancer and disease but, by equal measure, they could

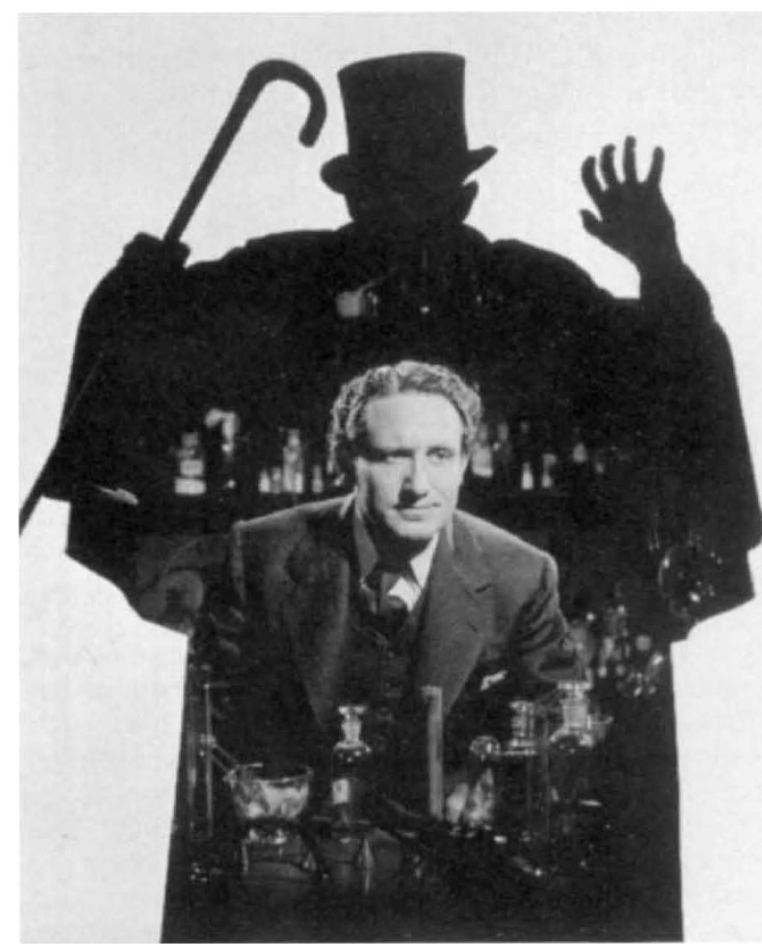

Creators of monsters and marvels - in the eyes of the public, genetic engineers have the power to do enormous good but, by the same token, they also have powers of untold potential evil.

be the cruel experimenters on human embryos and the like. Jekyll and Hyde are alive, well and hard at work creating transgenic monsters and marvels. There is both excitement about what genetic engineering can do and concern about what it could do.

Some of this concern is perhaps more the result of confusion than consideration. Some is not. And hence any book explaining in a fair and accessible fashion just what genetic engineering can do and what the moral issues are is to be warmly received. Unfortunately, authors competent at explaining both the scientific facts and the ethical debate are rare, so two sorts of book tends to emerge: those concentrating on the ethics and those concentrating on the genetics. Gene Future is in the latter class.

The structure of the book is very much of a form. The author starts by discussing DNA and inheritance, then moves on to explain what manipulations can be done, how they can be applied and what of good and bad may come out of it all. His treatment of the facts is always clear and rigorous. If anything, this rigour tends to degrade the text into a series of lists which seem out of place in a 'popular' book. These lists, however, serve Lee's overriding point, namely that the promised genetic revolution is upon us and we must now decide what we want to do with it.

As intimated, Lee does not go on to provide a guiding hand into the moral debate. Although he typically illuminates the scientific facts around the domain of the ethical 눈 issues, the difference between germ line and soma$\div$ tic modification for inst苋 ance, he does not lay out just what the alternative F moral standpoints might be. Instead he describes the research bodies thinking about the issues and the policing authorities watching over the new genetics. Is this intended to reassure us?

One that it does not reassure is Colin Tudge. He argues that the policing agencies are devoid of moral authority. Lawyers are law enforcers, not moral advisers. As might be guessed from this strong attitude, the author is not satisfied simply to lay out the science. It is indeed the moral problems posed by the new genetics that inform much of Tudge's book. His is not, however, the book of an analytical philosopher dissecting the alternatives and deriving the consequences. It is more an advocacy of a moral standpoint and is by turns invigorating and infuriating. Although most of the book is a very accessible introduction to evolutionary and molecular genetics, the author reveals his colours in the final few chapters. Here he puts genetic engineering in the context of the problem of technology as a whole. This in turn he merges with what he sees as the great problem facing us: ever-expanding populations moving us relentlessly towards the brink.

Whereas Lee realizes the same problem and then retreats, Tudge tackles the issue head on. His solution is twofold. First, he suggests a programme for public scientific literacy. Understanding must come before judgement. Citing Christ and John 
Maynard Smith he also argues that "only the meek can inherit the earth": unless, in opposition to what game-theory tells us, we are all more selfless we shall go the way of all flesh. To impose the altruistic spirit, we must, he insists, reaffirm religious ideals and reinstate a priest class. Is the author arguing that we should all be religious or that a controlling class should manipulate the masses by encouraging religious ideals? Either way, from an understanding of the author's possible religious inclinations, many of his opinions start to fit into a mould. His appeal against mechanistic views of consciousness and of life, for instance, have a decidedly metaphysical ring to them.

Although I, and I suspect many others, can concur with many aspects of the author's ethical stance, for instance his concern for a moral standard in the treatment of animals, his affirmation of religion is to me unsatisfactory. Just as science got us into this mess, is not science the best way out? But how then, one might argue, can we expect the necessary selfless acts of martyrs and saints? Do we not need a higher ideal to inform our morality? Perhaps so, but not one, I would argue, based on unquestioning obedience. During the siege of Leningrad in 1941-42, at least nine scientists, Lee reports, at the Vavilov Institute of Plant Diversity starved to death rather than eat the seeds that they had been entrusted to preserve. Although I find this story almost too incredible (and would like to know more), I would also like to believe that they died because of their understanding of the importance of biodiversity. If so, then it is perhaps to these few that we must look for inspiration, for, unlike any deism, their higher ideal was rooted in solid ground.

Laurence D. Hurst is in the Department of Genetics, University of Cambridge, Downing Street, Cambridge CB2 3EH, UK.

\section{Strong medicine for weak stomachs}

\section{Walter Gratzer}

The Literary Companion to Medicine. By Richard Gordon. Sinclair-Stevenson: 1993. Pp. 431. £18.

AN odd lot, doctors. To engage from choice in the exploration of other people's bodily orifices or shoving a fist into an abdomen full of quivering offal surely betokens an unusual cast of mind. Are they perhaps seeking to exorcise the daemons of death and disease, or is there a touch of necrophilia in some dark crevice of the psyche? Richard Gordon's excellent but unsettling anthology will do nothing to allay such suspicions, for it has much of the grisly fascination of the Hunterian Museum. It progresses from Sir Thomas Browne on the disposal of the dead - death here at its most deliquescent, all worms and snakes "out of the spinall marrow", lixivious liquors of the body and grave wax - through Pujol the Petomane, the musical virtuoso of the anal sphincter, to George Orwell, down and out among the paupers in a Paris ward of primaeval squalor, to conclude magnificently with Gordon's own finest creation, Sir Lancelot Spratt, the imperious surgeon in Doctor in the House.

Orwell's memoir is not easily eradicated from the memory. In Hôpital X (which Gordon identifies as the melancholy Hôpital Vaugirard) he looks on as death releases an old man from some hideous disease, only a foot or two away: a "natural" death, Orwell ruminates, such as you pray for in the Litany. "Natural' death, almost by definition, means something slow, smelly and painful. Even at that it makes a difference if you can achieve it in your own home and not in a public institution. This poor old wretch who had just flickered out like a candle-end was not even important enough to have anyone watching by his deathbed. He was merely a number, then a 'subject' for the students' scalpels . ..." Powerful stuff and not for weak stomachs. More Grand Guignol, this time unfamiliar, at least to me, is a description by the Hungarian humorist, Frigyes Karinthy, writing in 1935, of his operation for the removal of a brain tumour under local anaesthetic - the very stuff of nightmares. Gordon has a keen ear for commanding prose, and his chosen passages from Melville, Trollope, Flaubert (translated by himself) and Robert Louis Stevenson are guaranteed to bring up gooseflesh or make the gut heave.

There are gruesome narratives from fiction and fact of the deeds of the Resurrection Men, though Jeremiah Cruncher from The Tale of Two Cities does not appear, nor yet the reprobates who robbed the dead on the Napoleonic battlefields of their teeth to grace the dentures of well-heeled parties back home ("Waterloo teeth" they were called). He includes some fragments of verse by George Crabbe, but not the poet's story of how, when he was a medical student, his landlady found a dead child in a cupboard in his room, which she conviced herself was her own recently departed William. In France there were no Resurrectionists: the bodies of those who died in hospital and were not claimed within the day were rushed to the dissecting rooms. As to these, I would have included the lurid account by Hector Berlioz of his first day as a medical student in one such charnel house. Eugene Sue was another who described these and other loathsome aspects of life in the Paris of the poor during the last century.

To list omissions is too easy of course, and probably otiose, for a good anthology has to reflect the tastes, literary and historical, of its editor and nobody else. All the same, while I found it hard to relate the extracts from Brillat-Savarin, Malthus, Jane Austen and one or two others to medicine (not of course that they are any the worse for that), I did rather miss A. J. Cronin, Francis Brett Young and Axel Munthe, all celebrated for their tales of the medical life in their time. No doubt Gordon felt the style to be too faded for the robuster tastes of today. But then Gordon scores a wholly unexpected winner with a clutch of Victorian lady novelists, all of whom laid aside the stethoscope for the pen. The extracts, which could adorn a Stuffed $O w l$ of prose writing, will leave Messrs Mills and Boon reeling.

Gordon's choice of verse includes broad swathes of W. E. Henley - surprisingly affecting on his long years as a patient and of Robert Bridges, the doctor poet laureate (the subject incidentally of one of the great newspaper headlines, which appeared after he had failed on his arrival in New York to recite for the reporters who greeted him at the dockside: "King's Canary Won't Sing", it proclaimed). Gordon does not mention Bridges' account of life in the outpatient clinic at Bart's, where the average invalid received 1.28 minutes of attention, even if at death's door, and the casualty doctor 0.7 pence per examination. For my part, I think I should have included Thomas Hood ("I vowed that you should have my hand/But fate gives us denial/You'll find it there at Mr Bell's/In spirits in a phial" ... and more in this vein), and perhaps a restorative dash of Belloc? Or among more modern and substantial figures, there are William Carlos Williams and Danny Abse, who both drew inspiration from their doctoring. But perhaps more typical was Sir John Hill, MD, playwright, who lives on in Garrick's celebrated epigram: "For physic and farces his equal there scarce is/His farces are physic; his physic a farce is." You will not find the hapless Hill in Gordon's pages, but there are riches in plenty and catharsis for all; and if you are of a nervous or hypochondriacal disposition, then take comfort from Napoleon's observation at a low point in his life: "Well, at least there is always death".

Walter Gratzer is in the MRC Muscle and Cell Motility Unit, King's College London, 26-29 Drury Lane, London WC2B 5RL, UK. 